\title{
Ulasan Artikel: Elemen dalam Buku Indie: Satu Kajian Grounded Theory Terhadap Mahasiswa Universiti Pendidikan Sultan Idris
}

\author{
Article Review: Elements in Indie Books: A Grounded Theory Study on Sultan Idris \\ Educations University's Undergraduate Students
}

\author{
KRISTOPHER WILLIAMSON ${ }^{1}$
}

\begin{abstract}
Independent book publishing in Malaysia has presented typically younger readers with a popular platform for connecting with familiar realities and lived social situations. At the same time, there is resistance to the success of these "indie books" on political, economic, and social fronts by groups that are entrenched in the normative order. At the titular level, Muhammad Atiullah Othman, Nadarajan Thambu, and Siti Noranizahhafizah Boyman's study, "Elemen dalam Buku Indie: Satu Kajian Grounded Theory Terhadap Mahasiswa Universiti Pendidikan Sultan Idris," appears to offer a case study on the perceptions of university students toward the various elements found within some indie books. Upon closer examination, however, their study largely ignores student responses and criticizes the entire industry for the perceived and projected negative impact it will have on the nation. The disconnect between the data and their claims is compounded by the authors' unsupported and highly subjective moral judgments, despite multiple instances of their own unethical academic writing practices.
\end{abstract}

Keywords: article review, indie books, grounded theory, literature, young readers

Kejayaan dan populariti penerbitan buku indie di Malaysia di sepanjang dekad yang lalu telah mengubah landskap sastera negara. Seperti halnya dengan mana-mana perubahan aspek sosial, ada pihak yang cuba menentangnya dari sudut sosial (Muhammad Rashidi \& Siti Nur Hidayah 2016), politik (BTN 2015), mahupun ekonomi (Universiti Terbuka PTS 2012). Umum mengetahui mereka yang melakukan tindakan sedemikian rupa biasanya melakukannya untuk menguatkan status quo sambil memanfaatkan diri mereka sendiri, walaupun hakikatnya ahli akademik dalam bidang sains sosial ini sepatutnya melibatkan diri dalam perbincangan tentang perubahan ini dengan mendasarkan penyelidikan mereka dalam teori, kesusasteraan terdahulu, atau analisis data yang objektif.

Saya secara umumnya tidak suka membaca artikel yang dikarang oleh Muhammad Atiullah Othman, Nadarajan Thambu, dan Siti Noranizahhafizah Boyman (selepas ini, penulis) yang berjudul "Elemen dalam Buku Indie: Satu Kajian Grounded Theory Terhadap Mahasiswa Universiti Pendidikan Sultan Idris" dalam Vol. 14 (Disember 2018) Jurnal ini. Premis artikel mereka, buku yang diterbitkan oleh penerbit indie atau alternatif ini "amat buruk" dan memberikan kesan negatif kepada pembaca

${ }^{1}$ Kristopher Williamson, Ph.D. candidate, Dept. of Southeast Asian Languages and Cultures, Asia-Africa Institute, University of Hamburg (Universität Hamburg), Edmund-Siemers-Allee 1, Flügel Ost, 20146 HAMBURG, Germany, email: kecak@hotmail.com. 
"yang mudah dipergunakan" (Muhammad Atiullah et al. 2018: 50), dan boleh mengancam negara pada generasi yang akan datang. Tuntutan ini sepatutnya datang daripada analisis berasaskan teori yang berpandukan tanggapan soal selidik oleh pelajar-pelajar sarjana di Universiti Pendidikan Sultan Idris, di mana ketiga-tiga penulis bertugas sebagai pensyarah kanan di Jabatan Pengajian Kemasyarakatan \& Kewarganegaraan di universiti tersebut.

Saya kuat mengatakan bahawa ketiga-tiga penulis telah mengasilkan satu artikel yang berat sebelah dan sensasi dan tidak menunjukkan kesinambungan antara analisis data yang telah dikumpul dengan lemah dan kesimpulannya. Walaupun saya mempunyai banyak kritikan, saya akan memfokuskan kebimbangan saya untuk beberapa isu sahaja. Ini termasuk ketidakselarasan antara postmodernisme, eksistensialisme, dan grounded theory dengan kajian yang sepatutnya; ayat-ayat plagiat yang dijumpai di dalam deskripsi konsep dan juga di dalam data wawancara itu sendiri; dan pendekatan yang menghakimi dan bias dalam menangani topik itu tanpa sebarang objektiviti atau rawatan akademik bahan tersebut.

Para penulis menawarkan pengenalan ringkas penerbitan indie di Malaysia dengan sematamata menggunakan sumber yang menggambarkan perniagaan dan produk mereka secara negatif (BTN 2015; Muhammad Rashidi \& Siti Nur Hidayah 2016). Mereka menyamakan perniagaan bervariasi ini dan kumpulan penulisnya yang lebih bervariasi sebagai "gerakan" yang, secara semula jadi, "bersifat memberontak, agresif dan radikal" (Muhammad Atiullah et al. 2018: 39). Para penulis melompat ke satu perbincangan pendek tentang metodologi -yang menawarkan definisi grounded theory oleh Glaser dan Strauss yang tidak disebut atau ditunjuk lagi- sebelum kembali ke serangan lanjut mengenai aspek negatif buku indie tertentu.

Oleh kerana artikel ini dilabelkan sebagai kajian grounded theory, maka bahagian seterusnya yang berkaitan dengan penyampaian data daripada soal selidik dengan pelajar UPSI yang sepatutnya dijadikan bahan utama dan harus ditangani untuk analisis mereka. Bahagian ini mengenal pasti tiga unsur utama iaitu "kebebasan, realistik, dan santai" (Muhammad Atiullah et al. 2018: 40-41), yang dinyatakan dalam jawapan soal selidik. Tetapi "perbincangan" data ini kembali kepada ulasan yang menghakim dan subjektif mengenai kandungan dan gaya buku indie. Ia menunjukkan bagaimana gaya penulisan indie itu merangkumi isu-isu seperti "seks bebas," kebimbangan LGBTQ, bahasa yang tidak sopan, dan pemikiran dan ideologi yang "songsang" (Muhammad Atiullah et al. 2018: 48). Para penulis kemudian menentukan pascamodenisme dan eksistensialisme -mungkin dalam usaha untuk menghubungkan unsur-unsur negatif yang mereka telah labelkan dalam buku-buku indie Malaysia ke klasifikasi sastera yang lebih luas- sebelum menyimpulkannya dengan memberi penekanan tentang bahaya buku-buku ini kepada masa depan negara.

Bahan utama kajian ini adalah data soal selidik berstruktur oleh pelajar UPSI. Dengan menggunakan pendekatan grounded theory, penulis perlu menganalisis data ini tanpa sebarang prasangka (Glaser \& Strauss 1967). Allan (2003: 1) mencatatkan bahawa "analisis data temu duga dalam penyelidikan kualitatif, cenderung untuk menghasilkan gambaran tentang pandangan interpretivis mengenai peristiwa, sedangkan analisis data (grounded theory) melibatkan pencarian konsep-konsep di belakang realiti dengan mencari kod, kemudian konsep dan akhirnya kategori". Masalahnya di sini berlaku apabila soal selidik ini sendiri yang -penulis tidak benar-benar memberikan senarai soalan yang ditanya tetapi cuma mensasarkan beberapa perkataan yang perlu dijawab- dianjurkan untuk memacu peserta kajian ke arah yang tertentu. Tanggapan-tanggapan yang sempit diterangkan dengan begitu sama dengan memasukkan kata kunci yang sama. Ini menunjukkan bahawa peserta kajian telah dipupuk melalui soalan. Tanpa bertanya soalan yang terbuka, ketiga-tiga penulis itu hanya boleh mendapatkan jenis respons yang mereka tentukan melalui soalan yang berstruktur. 
Selain itu, tiada maklumat disediakan mengenai para peserta kajian selain fakta bahawa mereka adalah pelajar UPSI. Ini menjadikan kajian ini sukar bagi penyelidik lain untuk menghasilkannya semula. Kebimbangan selanjutnya timbul daripada kemungkinan bahawa peserta kajian merupakan pelajar langsung penulis artikel sendiri. Oleh kerana kecenderungan dan bias penulis, ini boleh mengubah jawapan peserta kajian berdasarkan apa yang diharapkan oleh pensyarah-pensyarah mereka.

Apa yang lebih bermasalah adalah cara data itu dikaitkan -atau tidak dikaitkan- dengan 'penemuan' penulis. Para penulis mengkategorikan jawapan pelajar terhadap soalan mereka tentang buku indie sebagai memihak kepada tiga unsur utama, iaitu kebebasan, realistik dan santai. Dalam beberapa perenggan, para penulis berkongsi perihal postmodernisme dan eksistensialisme dan mendakwa bahawa ketiga-tiga unsur dalam buku indie Malaysia membolehkan mereka juga mengklasifikasikannya sedemikian rupa (Muhammad Atiullah et al. 2018: 50). Walaupun terdapat pelabelan yang tidak disokong, para penulis kemudian menulis bahawa "mutu persembahan buku indie adalah rendah dan masih kurang daya inteleknya kerana buku indie hanyalah bacaan santai" (Muhammad Atiullah et al. 2018: 50), yang jauh berbeza daripada kebanyakan karya eksistensialis yang lain.

Walaupun pembinaan kes yang lemah dan tidak berterusan dalam menghubungkan data dari respons peserta kajian kepada klasifikasi postmodernisme dan eksistensialisme, kebimbangan yang lebih besar ialah plagiarisme yang berlaku di sepanjang artikel tersebut. Dari ayat yang pertama lagi, secara bulat-bulat penulis telah mengambil definisi Muhammad Rashidi dan Siti Nur Hidayah (2016: 3) untuk perkataan 'indie'. Walaupun mereka telah memasukkan petikan di hujung ayat, tetapi ayat itu sendiri tidak dimasukkan di dalam tanda petikan, dan tidak menyebut nombor halaman di mana bahan itu diambil. Ini berlaku beberapa kali di sepanjang artikel, menjadikan tuntutan mereka ke atas kepincangan moral yang ada pada kandungan buku indie agak hipokrit dengan amalan penulisan mereka sendiri yang tidak beretika.

Selain itu, jawapan peserta kajian juga mengandungi contoh-contoh plagiarisme daripada artikel yang para penulis sebut dalam kajian mereka. Sebagai contoh, peserta kajian yang dikenal pasti sebagai CT30.2017 dan CI18.2017, kedua-duanya memplagiat definisi 'buku indie' daripada artikel Muhammad Rashidi dan Siti Nur Hidayah (2016: 5). Jika, sesungguhnya, para penulis telah mengekodkan jawapan pelajar dengan teliti menggunakan grounded theory, mereka sepatutnya menyedari kesamaan antara jawapan tersebut-atau menyedari plagiarisme secara terang-terangan daripada artikel yang sering mereka rujuk dalam artikel itu.

Ini menunjukkan tahap pemerhatian yang kurang terperinci-keperluan mutlak apabila cuba menggunakan grounded theory-dan keputusan yang buruk dalam memilih bahan tersebut sebagai wakil dalam kajian mereka. Kemungkinan lain ialah bahan pensampelan jawapan peserta dilihat sama ada terlalu kecil untuk kajian mereka, atau mereka cuba memilih jawapan yang sesuai dengan idea-idea yang telah mereka tetapkan terlebih dahulu.

Akhir sekali, ahli akademik tidak sepatutnya menerbitkan topik yang mereka tidak fahami. Dengan beribu-ribu buah buku yang telah diterbitkan oleh penerbit indie di Malaysia, adalah sangat tidak adil bagi ketiga-tiga penulis artikel ini untuk menggeneralisasikan setiap penulis indie dan buku-buku yang diterbitkan di bawah label indie itu sendiri.

Terdapat beberapa kajian mengenai aspek penerbitan buku indie di Malaysia yang memberi tumpuan kepada minat pembaca (Muhamad Faisal et al. 2018), politik identiti (Syazrul 2018), dan juga persamaan yang besar antara arus perdana dan penerbitan indie di negara ini (Muhammad Febriansyah 2016). Tetapi di dalam artikel ini, penulis lebih cenderung untuk meniru cakap-cakap pegawai hal ehwal agama yang konservatif dan badan-badan propaganda kerajaan tanpa menunjukkan kefahaman mereka bahawa ada sesetengah buku indie yang diterbitkan -dan dibaca 
tanpa paksaan- sebagai tindak balas akibat ketidakpuasan terhadap norma-norma masyarakat di zaman ini. Sebaliknya, para penulis menawarkan penghakiman dan generalisasi daripada akaunakaun ini sebagai 'buruk' (Muhammad Atiullah et al. 2018: 50) tanpa mempedulikan apa-apa proses akademik untuk menunjukkan bagaimana mereka sampai pada kesimpulan ini, malah mereka juga telah pergi lebih jauh dengan melabelkan seorang penulis indie sebagai 'penulis simbol seks' tanpa memberikan konteks, sumber, atau perbincangan mengenai tuntutan itu.

Penulis-penulis juga mengetengahkan beberapa isu -jantina, seksualiti, kebebasan bersuara, hak asasi manusia, dan pelbagai ideologi- yang mereka anggap sebagai topik yang tidak sesuai untuk pembaca yang 'mudah dipergunakan' (Muhammad Atiullah et al. 2018: 50). Walau bagaimanapun, apa yang ditemui oleh para penulis daripada peserta kajian adalah rata-rata peserta kajian tertarik dengan tema dan gaya buku indie ditulis. Pada saya, daripada memberikan penilaian moral yang selektif, adalah lebih bermanfaat -dan semestinya lebih akademik- bagi para penulis untuk melakukan temuduga secara separa berstruktur untuk meneroka beberapa sebab mengapa rakyat Malaysia yang muda dan berpendidikan semakin mengenali laluan alternatif yang diterbitkan oleh penerbit indie. Juga lebih menarik jika para penulis berhadapan dengan topik-topik yang sering dilabel tabu ini dengan semangat ingin tahu secara akademik yang seterusnya akan mewujudkan perbincangan.

Adalah menjadi harapan saya bahawa penulis mengambil satu langkah ke belakang daripada pendekatan sempit mereka sama ada dalam topik ini atau topik-topik yang lain untuk menimbang semula skop yang lebih besar tentang apa sebenarnya yang sedang berlaku dan kepentingannya, daripada menumpukan unsur masyarakat yang menimbulkan rasa kurang senang dalam diri mereka sendiri sehingga menyerang golongan-golongan tertentu secara peribadi melalui kajian yang dihasilkan secara semberono. Saya berharap semoga satu hari nanti saya akan dapat membaca apaapa kajian objektif dan ilmiah yang belum ditawarkan oleh mereka.

\section{References}

Allan, G. 2003. A critique of using grounded theory as a research method.Journal of Business Research Methods 2(1): 1-10.

BTN (Biro Tatanegara). 2015. Gerakan Indie di Malaysia. (online) https://archive.org/details/GerakanIndieDiMalaysia. Retrieved: 29 August 2019.

Glaser, B.G., \& Strauss, A.L. 1967. The Discovery of Grounded Theory: Strategies for Qualitative Research. New Brunswick, NJ: AldineTransaction.

Muhamad Faisal Ashaari, Mohd. Firdaus Hamzah, Lily Yaakub, \& Rosmawati Mohamad Rasit. 2018. Tarikan terhadap buku indie dalam kalangan pembaca muda di Malaysia. Islāmiyyāt 40(2): 169-78.

Muhammad Atiullah Othman, N. Thambu, \& Siti Noranizahhafizah Boyman. 2018. Elemen dalam buku indie: satu kajian grounded theory terhadap mahasiswa Universiti Pendidikan Sultan Idris. International Journal of Islamic Thought 14: 38-51.

Muhammad Febriansyah. 2016. Penerbit Buku Indie: Benarkah Anti Arus Perdana?. Dewan Sastera, 46, 54-56. (online) https://www.academia.edu/29823830/PENERBIT_BUKU_INDIE_BENARKAH_ANTI_ARUS_ PERDANA. Retrieved: 3 September 2019.

Muhammad Rashidi Wahab \& Siti Nur Hidayah Kusnin. 2016. Laporan Awal: Sorotan Fenomena Buku Indie di Malaysia. (online) https://dokumen.tips/documents/laporan-awal-sorotanfenomena-buku-indie-di-bukupusat-pengajian-usuluddin-fakulti.html. Retrieved: 3 September 2019. 
Syazrul Aqram. 2018. Penerbit indie dalam industri perbukuan di Malaysia, sastera dan perlawanan Persepsi. Conference paper. Seminar Sehari Isu-Isu Mutakhir, Dewan Bahasa dan Pustaka, Kuala Lumpur.

(online) http://pemacudbp.dbp.gov.my/fm/fmDload.aspx?ti=2795DC359B9A463F12986574BA0CF 07D\&tl=\&type=.pdf. Retrieved: 3 September 2019.

Universiti Terbuka PTS. 2012. Risiko Penerbitan Buku Berbahasa Melayu Rendah. (online) http://universitipts.com/index.php/site/comments/risiko_penerbitan_buku_berbahasa_me layu_rendah_popular_tidak_lagi_menj. Retrieved: 10 August 2019. 